\title{
PERANCANGAN TIMBANGAN PENCATAT HASIL PANEN OTOMATIS MENGGUNAKAN MIKROKONTROLER BERBASIS WEB DAN DATABASE
}

\author{
Rusdiyanto $^{1}$, Zulfauzi ${ }^{2}$, Antoni Zulius ${ }^{3}$ \\ 1,2Program Studi Informatika, Universitas Bina Insan, Lubuklinggau \\ ${ }^{3}$ Program Studi Rekayasa Sistem Komputer, Universitas Bina Insan, Lubuklinggau \\ e-mail: ${ }^{1}$ rusdiyanto@univbinainsan.ac.id, ${ }^{2} z u l f a u z i @$ univbinainsan.ac.id, \\ 3antoni.zulius@univbinainsan.ac.id
}

\begin{abstract}
Abstrak
Hasil pertanian dan peternakan di Indonesia belum tercatat dengan baik kalau pun sudah tercatat tetapi data yang ada belum akurat karena data yang di dapat melalui survey langsung ke petani atau ke peternak dimana mereka terkadang lupa dengan hasil panen yang di dapat dalam beberapa tahun kebelakang sehingga terkadang survey yang dilakukan tidak akurat dan data yang di dapat kurang cepat sampai ke Pemerintah Pusat dalam hal ini adalah Kementerian Pertanian dan Peternakan selain itu dana yang digunakan untuk melakukan survey tersebut sangat besar karena melibatkan banyak orang. Dengan menggunakan Sistem Mesin Timbangan Pencatat Hasil Panen Otomatis menggunakan Mikrokontroler 328P berbasis Web dan Database sebagai Media Penyimpanan dan Monitoring Data Hasil Panen dapat dipercepat data sampai ke Pemerintah Pusat dan data yang didapat juga akurat karena langsung di dapat dari hasil timbangan para petani. Sistem ini akan menyimpan data hasil panen dari petani ke dalam komputer yang langsung terhubung ke perangkat timbangan pencatat hasil panen otomatis secara lokal, data yang di kumpulkan disajikan dalam bentuk grafik sehingga mudah untuk melakukan analisis hasil panen dari setiap musim panen. Data hasil panen juga dapat di unduh dari komputer yang terhubung ke perangkat timbangan pencatat hasil panen otomatis dalam bentuk excel. Diharapkan sistem ini dapat mempercepat proses pencatatan hasil panen dan dapat membantu para peneliti dalam bidang pertanian maupun peternakan untuk menganalisis masalah yang terjadi pada hasil panen karena data tersimpan di dalam database.
\end{abstract}

Kata kunci-3-5 ATMega 328P, Website, Database, Pencatat Hasil Panen Otomatis

\begin{abstract}
The results of agriculture and animal husbandry in Indonesia have not been well recorded even if they have been recorded but the data is not accurate because the data can be obtained through direct surveys to farmers or breeders where they sometimes forget about the yields obtained in the past few years so that sometimes the survey which is done inaccurately and the data that can be obtained less quickly to the Central Government in this case is the Ministry of Agriculture and Animal Husbandry in addition to the funds used to conduct the survey is very large because it involves many people. By using the Automatic Harvesting Scales Machine System using 328P Web-based Microcontroller and Database as a Data Storage and Monitoring Media Harvest Data can be accelerated up to the Central Government and the data obtained is also accurate because it can be directly obtained from the scales of the farmers. This system will store crop yield data from farmers into a computer that is directly connected to the automatic harvesting scales device locally, the data collected is presented in graphical form so that it is easy to analyze yields from each harvest season. Harvest data can also be downloaded from a computer connected to an automatic harvesting device weighing device in
\end{abstract}


the form of Excel. It is hoped that this system can speed up the process of recording yields and can help researchers in agriculture and animal husbandry to analyze problems that occur in crop yields because the data is stored in a database.

\section{Keywords-3-5 ATMega 328P, Website, Database, Automatic Harvesting Recorder}

\section{PENDAHULUAN}

Pada era serba digital sekarang ini semua aspek pendukung kegiatan manusia dituntut dapat mempermudah manusia guna mendukung mobilitas manusia. Mulai dari peralatan-peralatan yang ada di lingkup rumah tangga, industri, pertanian, peternakan, dan perdagangan. Tidak menutup kemungkinan juga alat dalam lingkup pertanian dan peternakan. Alat pengukur yang digunakan pun dituntut serba canggih untuk mempermudah pekerjaan manusia mengingat begitu sibuknya dalam proses perdagangan khususnya dalam lingkup pasar tradisional.

Hasil pertanian dan peternakan di Indonesia belum tercatat dengan baik kalau pun sudah tercatat tetapi data yang ada belum akurat karena data yang di dapat melalui survei langsung ke petani atau ke peternak dimana mereka terkadang lupa dengan hasil panen yang di dapat dalam beberapa tahun kebelakang sehingga terkadang survei yang dilakukan tidak akurat dan data yang di dapat kurang cepat sampai ke Pemerintah Pusat dalam hal ini adalah Kementerian Pertanian dan Peternakan selain itu dana yang digunakan untuk melakukan survey tersebut sangat besar karena melibatkan banyak orang. Dengan menggunakan Sistem Mesin Timbangan Pencatat Hasil Panen Otomatis menggunakan Mikrokontroler 328P berbasis Web dan Database sebagai Media Penyimpanan dan Monitoring Data Hasil Panen dapat dipercepat data sampai ke Pemerintah Pusat dan data yang didapat juga akurat karena langsung di dapat dari hasil timbangan para petani. Sistem ini akan menyimpan data hasil panen dari petani ke dalam komputer yang langsung terhubung ke perangkat timbangan pencatat hasil panen otomatis secara lokal, data yang di kumpulkan disajikan dalam bentuk grafik sehingga mudah untuk melakukan analisis hasil panen dari setiap musim panen. Data hasil panen juga dapat di unduh dari komputer yang terhubung ke perangkat timbangan pencatat hasil panen otomatis dalam bentuk excel. Diharapkan sistem ini dapat mempercepat proses pencatatan hasil panen dan dapat membantu para peneliti dalam bidang pertanian maupun peternakan untuk menganalisis masalah yang terjadi pada hasil panen karena data tersimpan di dalam database.

Timbangan digital menjadi populer sebagai perkembangan dari teknologi pada saat ini. Timbangan digital dapat dibangun dengan menggunakan input sensor load cell dipadukan dengan mikrokontroler sebagai aspek pengendalinya [1] [2] [3].

$$
\text { Beberapa penelitian yang }
$$
menerapkan prinsip timbangan digital dalam industri perdagangan yaitu membangun timbangan buah digital dengan keluaran berat dan harga dengan menggunakan sensor load cell sebagai input dari timbangan dan mikrokontroler Atmega32 sebagai pengendali [4].

Seiring berkembangnya penelitian yang membahas timbangan digital, penggunaan timbangan tidak hanya terbatas dalam mengukur berat atau massa suatu benda, tetapi juga dihubungkan dengan berat badan ideal (Body Mass Index-BMI) dengan input tentu saja berat dan tinggi badan [5] [6].

Penerapan timbangan digital juga dapat diterapkan dalam kesehatan [7] [8] [9]. 
Konsep yang digunakan dengan merancang bangun sistem pemantau perkembangan berat badan balita.

Di dalam bidang industri, timbangan digital otomatis digunakan sebagai mesin sortir ikan berdasarkan berat badan dengan mekanisme pergerakan konveyor [10]. Selain itu juga digunakan sebagai sistem kontrol penimbangan dalam industri tembakau [11].

Atas dasar pertimbangan tersebut peneliti tertarik untuk mengambil objek penelitian dengan judul Perancangan Timbangan Pencatat Hasil Panen Otomatis Menggunakan Mikrokontroler Berbasis Web dan Database.

\section{TINJAUAN PUSTAKA.}

\subsection{Mikrokontroler Atmega328P}

Mikrokontroler atau sering dinamakan pengontrolan tertanam (Embedded Controler) adalah suatu system yang mengandung masukan/ keluaran, memori, dan Prosessor yang digunakan pada produk elektronik seperti Pemutar Video pada mobil, Telepon dan Mesin Cuci. Pada Prinsipnya Mikrokontroler adalah sebuah komputer berukuran kecil yang dapat digunakan untuk mengambil keputusan melakukan hal-hal yang bersifat berulang dan dapat berinteraksi dengan perangkat-perangkat eksternal, seperti sensor ultrasonik untuk mengukur jarak terhadap suatu objek, penerima GPS untuk memperoleh data posisi kebumian dari satelit dan motor untuk mengontrol gerakan Robot [12].

Mikrokontroler ATmega 328P adalah sebuah Microchip picopower 8 bit AVR berbasis yang dikombinasikan dengan 32 KB ISP Flash memori dengan kemampuan membaca dan menulis, 1024 Bytes EEPROM, 2KB SRAM, 23 jalur Input dan Output, 32 Jalur Register, Tiga timer/counter dengan mode pembanding, Interrupt Keluaran dan Masukan, USART Serial yang dapat di Program, Byte yang dilewatkan melalui 2 jalur Serial Interface, SPI Serial Port, 6 Kanal 10 bit Analog/Digital Konverter, Pembatas waktu yang dapat di program dengan Osilaator Internal, dan Lima Pilihan Perangkat Lunak untuk mode hemat energi. Perangkat ini bekerja pada tegangan 1,8 Volt sampai dengan 5 Volt.

\subsection{Load Cell}

Load Cell adalah alat elektromekanik yang biasa disebut transducer, yaitu gaya yang bekerja berdasarkan prinsip deformasi sebuah material akibat adanya tegangan mekanis yang bekerja, kemudian merubah gaya mekanik menjadi sinyal listrik. Untuk menentukan tegangan mekanis didasarkan pada hasil penemuan Robert Hooke, bahwa hubungan antara tegangan mekanis dan deformasi yang diakibatkan disebut regangan. Regangan ini terjadi pada lapisan kulit dari material sehingga memungkinkan untuk diukur menggunakan sensor regangan atau Strain Gauge. [13]

\subsection{PHP}

PHP (Personal Hypertext

Preprocessor) adalah bahasa server side scripting yang menyatu dengan Hypertext Markup Language (HTML) untuk membuat halaman web yang dinamis. Karena PHP merupakan server side scripting maka sintak dan perintah-perintah PHP akan dieksekusi ke server kemudian hasilnya dikirim ke browser dalam format HTML [14].

\section{METODOLOGI PENELITIAN}

\subsection{Perancangan Sistem}

\subsubsection{Spesifikasi alat}

- Mikrokontroler Atmega328P

- Sensor Load Cell;

- Ethernet Shield;

- Kabel Jumper;

- Solenoid Door Lock;

- Note Book (PC);

\subsubsection{Rancangan Elektronik}

Gambar 1 berikut menyajikan rangkaian sistem secara keseluruhan sistem lengkap dengan catu daya yang digunakan. 


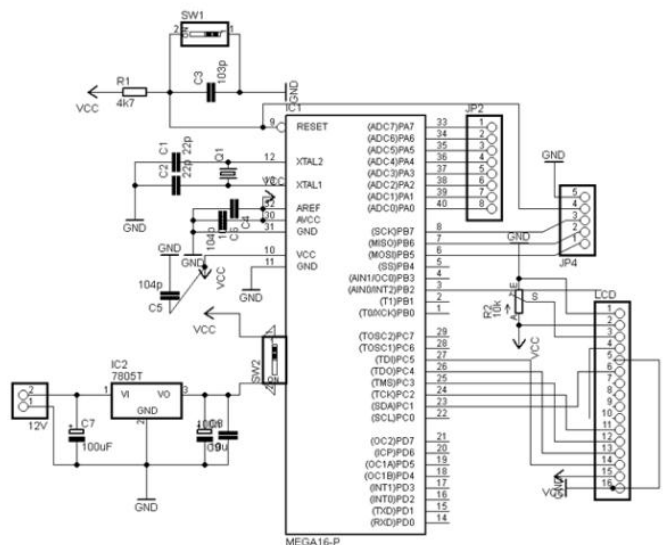

Gambar 1. Rangkaian Sistem

\subsection{Desain Sistem}

Setelah mendapatkan inti dari permasalahan peneliti membuat desain sistem berupa blok diagram system pencatat hasil panen otomatis yang dapat menyimpan data dan dapat melihat hasil timbangan dengan website yang tampilannya berupa grafik. Gambar 2 berikut mendeskripsikan alur kerja dari sistem. Gambar 3 menyajikan diagram alir sistem secara keseluruhan.

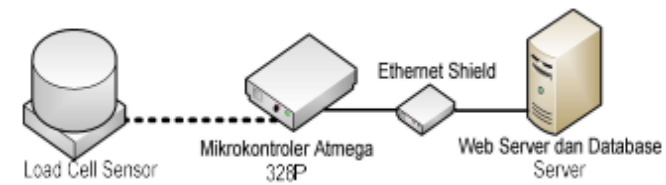

Gambar 2. Alur Kerja Sistem

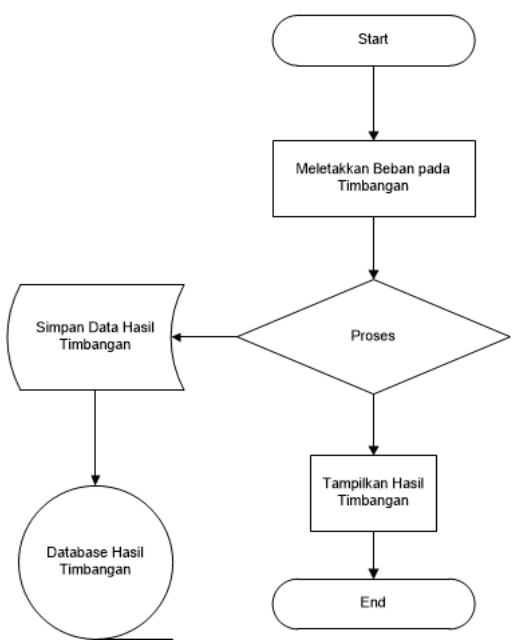

Gambar 3. Flowchart Sistem

\section{HASIL DAN PEMBAHASAN}

\subsection{Hasil Perancangan}

Setelah melakukan analisis kebutuhan komponen dan perangkat pendukung untuk membuat sistem timbangan pencatat hasil panen Otomatis kemudian dilakukan pembuatan sistem dan hasil dari perangkat keras dan perangkat lunak dapat dilihat pada gambar 4 berikut :

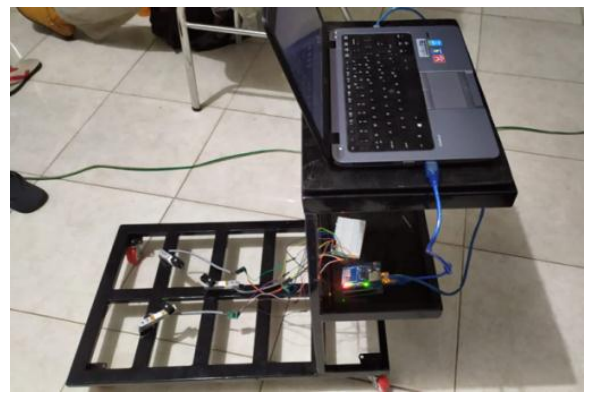

Gambar 4. Kerangka Timbangan dan

Posisi Peletakan Sensor Load Cell

Untuk mengakomodasi berat yang akan di tumpu maka timbangan di buat dari besi sehingga lebih kuat untuk menahan beban. Gambar 5 berikut menyajikan hasil dari perangkat pemroses sensor load cell.

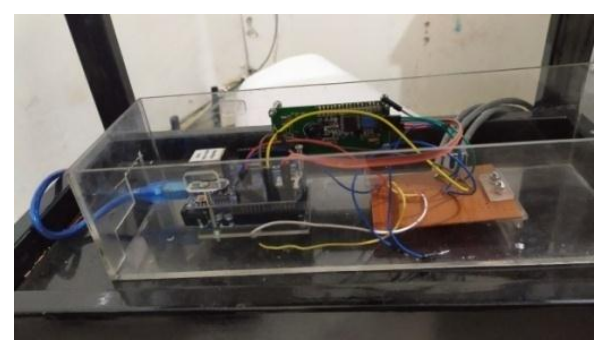

Gambar 5. Perangkat Pemroses Data dari Sensor Load Cell

Sebagai output dari sistem, peneliti menggunakan interface web untuk menampilkan datanya. Gambar 6 menampilkan halaman login dari sistem yang dirancang. 


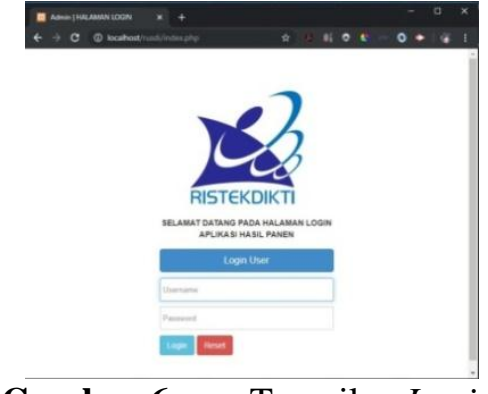

Gambar 6. Tampilan Login

Setelah pengguna Login seperti pada Gambar 6 pengguna akan diarahkan ke halaman awal yang berisi menu dari aplikasi yaitu menu Data Petani, Data Hasil Panen dan Dashboard Hasil Panen. Gambar 7 berikut menyajikan halaman awal sistem.

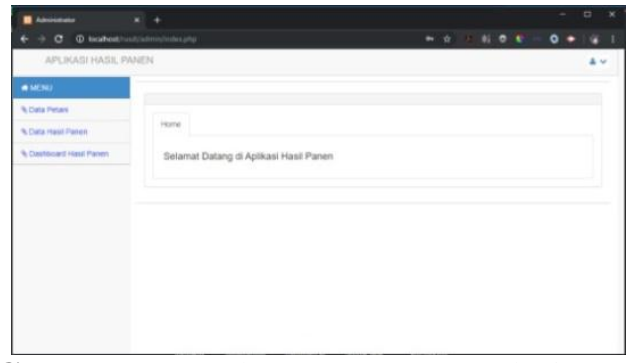

Gambar 7. Halaman Menu Awal Sistem

Sesuai dengan luaran sistem, hasil panen komoditas petani yang baru ditimbang akan ditampilkan dalam bentuk grafik sehingga memudahkan pengguna untuk melihatnya. Gambar 8 berikut menampilkan grafik hasil panen petani yang sudah ditimbang.

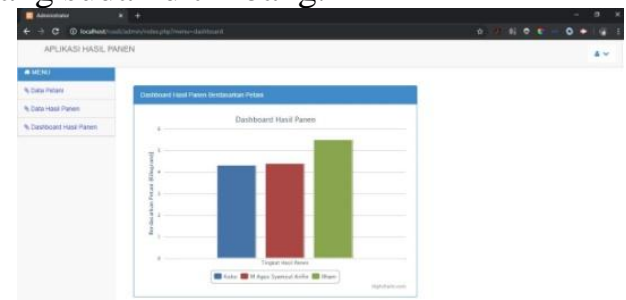

Gambar 8. Halaman Menu Awal Sistem

\subsection{Pengujian Sistem}

Pengujian merupakan salah satu langkah penting yang harus dilakukan untuk mengetahui apakah sistem yang dibuat telah sesuai dengan yang direncanakan, hal itu dapat dilihat dari hasil yang diperoleh dari hasil pengujian sistem. Pengujian sistem dimulai dari rangkaian power supply sebagai catu daya, sensor load cell, dan juga hasil pembacaan sensor ke dalam interface.

Tabel 1 berikut menyajikan hasil pengukuran catu daya.

Tabel 1. Pengujian Catu Daya

\begin{tabular}{cc}
\hline $\begin{array}{c}\text { Hasil } \\
\text { Ukur }\end{array}$ & Ket \\
\hline $12 \mathrm{Vac}$ & Input 12 V Trafo \\
$16 \mathrm{Vdc}$ & Output Dioda Brigde \\
& Output Regulator \\
$12 \mathrm{Vdc}$ & 7812 \\
& Output Regulator \\
$5 \mathrm{Vdc}$ & 7805 \\
\hline
\end{tabular}

Pengujian berikutnya yaitu Pengujian terhadap sensor Load Cell. Pengujian ini dilakukan untuk mengetahui kalibrasi dari sensor. Hasil kalibrasi yang didapatkan disajikan tabel 2.

Tabel 2. Pengujian Load Cell

\begin{tabular}{ccc}
\hline No. & Alat Standar $(\mathbf{K g})$ & $\begin{array}{c}\text { Alat Yang } \\
\text { Dirancang }(\mathbf{K g})\end{array}$ \\
\hline 1 & 0.1 & 0.110 \\
2 & 0.2 & 0.220 \\
3 & 0.3 & 0.320 \\
4 & 0.4 & 0.425 \\
5 & 0.5 & 0.510 \\
6 & 0.6 & 0.605 \\
7 & 0.7 & 0.715 \\
8 & 0.8 & 0.815 \\
9 & 0.9 & 0.910 \\
10 & 1.0 & 1.100 \\
\hline
\end{tabular}

\subsection{Pengujian Interface Sistem}

Pengujian interface sistem dilakukan dengan melihat tampilan hasil pembacaan sensor load cell. Gambar 9 berikut menyajikan hasil sensor yang dibaca pada serial monitor. 


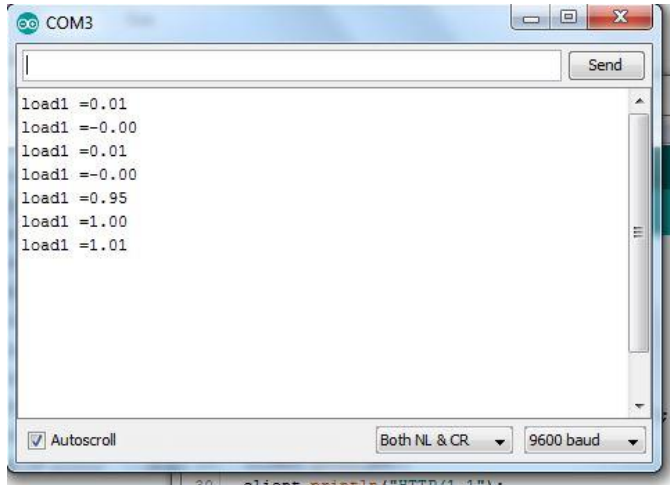

Gambar 9. Hasil Sensor Yang dibaca

Untuk nilai di bawah 0,5 yang dihasilkan oleh sensor tidak akan di masukkan ke dalam database karena Timbangan diatur hanya akan memasukkan beban minimal 500 gram ke dalam Database.

\section{KESIMPULAN}

Berdasarkan penelitian yang telah dilakukan melalui hasil pengujian dan pengukuran, maka dapa ditarik kesimpulan bahwa perancangan sistem timbangan pencatatan hasil panen dirancang menggunakan modul mikrokontroler atmega 328P berhasil diterapkan sebagai pengendali utamanya. Perancangan sistem timbangan digital dirancang sebagai akses otomatisasi timbangan yang sebelumnya dilakukan secara manual, sehingga dapat mempermudah seseorang untuk melakukan pekerjaan tanpa harus mencatat hasil berat dari beban yang terukur timbangan. Media penyimpanan data hasil penimbangan tercatat ke dalam database sistem dan bisa diakses kapan saja dan dimana saja.

\section{SARAN}

Saran untuk pengembangan selanjutnya adalah Untuk pengembangan penelitian ini akan menggunakan mikrokomputer, sebagai contoh Raspberry $P i$ atau Banana $P i$ untuk menghemat perangkat karena dengan menggunakan perangkat tersebut tidak di butuhkan lagi PC atau Laptop untuk menjalankan program Webserver dan Database Server.

\section{DAFTAR PUSTAKA}

[1] Yandra, E.F., Lapanporo, B.P. and Jumarang, M.I., 2016. Rancang Bangun Timbangan Digital Berbasis Sensor Beban $5 \mathrm{Kg}$ Menggunakan Mikrokontroler Atmega328. POSITRON, 6(1)

[2] Purba, G., 2017. Rancang Bangun Sistem Timbangan Otomatis Berbasis Atmega328.Universitas Sumatera Utara.

[3] Manege, P.M. and Allo, E.K., 2017. Rancang Bangun Timbangan Digital Dengan Kapasitas 20Kg Berbasis Microcontroller ATMega8535. Jurnal Teknik Elektro dan Komputer, 6(1), pp.57-62..

[4] Hidayani, T.U. and Miharani, T., 2013. Rancang Bangun Timbangan Buah Digital Dengan Keluaran Berat Dan Harga. AMIK GI MDP

[5] Kusriyanto, M. and Saputra, A., 2016. Rancang bangun timbangan digital terintegrasi informasi BMI dengan keluaran suara berbasis Arduino Mega 2560. Jurnal Fakultas Hukum UII, 22(4)

[6] Maulana, L. and Yendri, D., 2018. Rancang Bangun Alat Ukur Tinggi dan Berat Badan Ideal Berdasarkan Metode Brocha Berbasis Mikrokontroler. Journal of Information Technology and Computer Engineering, 2(02), pp.76-84.

[7] Hakim, B., 2017. Rancang Bangun Inkubator Bayi Multi Pasien dengan Pengendali Suhu dan Kelembaban serta Monitoring Berat Badan Bayi Secara Otomatis Berbasis Arduino Mega 2560. Universitas Muhammadiyah Jember. 
[7] Wahyu, S.T., 2017. TA: Rancang Bangun Sistem Otomatis Pemantau Pertumbuhan Balita Berbasis Mikrokontroler, Institut Bisnis dan Informatika Stikom Surabaya)..

[9] Kurniawan, R. and Sunardi, L., 2018. Perancangan Sistem Monitoring Perkembangan Balita Menggunakan Mikrokontroler Atmega328p Terintegrasi Dengan Database Mysql Di Posyandu Pian Raya Kabupaten Musirawas. Jusikom: Jurnal Sistem Komputer Musirawas, 3(2), pp.72-81.

[10] Pujono, P., Prasetia, I.M. and Santoso, A.F., 2019. Rancang Bangun Mesin Sortir Ikan Berdasarkan Berat Dengan Mekanisme Pergerakan Konveyor. Bangun Rekaprima: Majalah Ilmiah Pengembangan Rekayasa, Sosial dan Humaniora, 5(2, Oktober), pp.9-18.

[11] Irwanto, B., Kabib, M. and Winarso, R., 2019. Rancang Bangun Sistem Kontrol Penimbangan Tembakau Dengan Mikrokontroller Arduino Uno. Jurnal Crankshaft, 2(2).

[12] Kadir Abdul, 2015, Buku Pintar Pemrograman Arduino, Mediakom, Jogjakarta.

[13] Load Cell Sensor (http://www.kitomaindonesia.com/ar ticle/23/load-cell-dan-timbangan, diakses 27 Juli 2018).

[14] Nugroho, Adi, 2011. Perancangan dan Implementasi Sistem Basis Data, Andi Offset, Yogyakarta. 